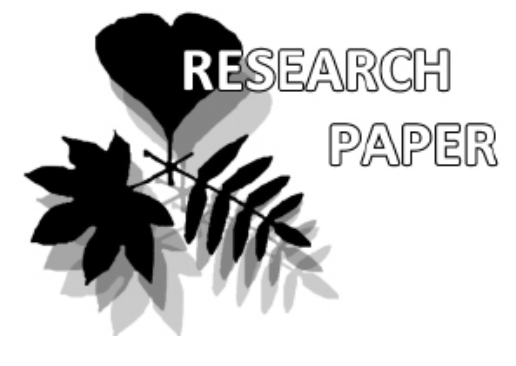

Sophie Shulman*

e-mail: shulmansophie@gmail.com

Calvin B. Stewart

e-mail: cbgil@shaw.ca

Victoria, B.C. V8X 4N5, Canada

* author for correspondence

Manuscript received: 20.03 .2015

Review completed: 29.03.2015

Accepted for publication: 01.04.2015

Published online: 31.05.2015

\section{Circadian rhythms in the motility (floating versus immersion) in Nereocystis luetkeana}

\author{
Sophie Shulman*, Calvin B. Stewart
}

\begin{abstract}
A B S T R A C T
Bull kelp, Nereocystis luetkeana, brown algae on the Pacific coast of North America in our field observations, when sunlight, actively position their stipes/blades exposed floating on the water surface, while at dusk get immersed hence invisible (with mostly the bulbs remaining observable on the surface). The suggested interpretation is of a phototropic circadian directional (vector) motility (as opposed to haphazard passive relocations due to low tides and water turbulence). This was unrecognized in the algae, generally rendered too primitive for such vector motor activity coordinated at the level of the whole organism. This mechanism is principally different from the previously recorded intracellular circadian rhythms in mitotic activity, photosynthesis and growth of juvenile sporophytes in some Laminariales. Floating exposure of the stipes/blades is maximal from sunrise till early afternoon and seems to gradually decrease later only to drop by the dusk. Those motility changes may occur as fast as within half an hour.
\end{abstract}

K e y w o r d s : bull kelp, motional circadian rhythms, phototropism, vector motility

\section{P E 3 Ю M E}

Шульман С., Стюарт К.Б. Суточный ритм в направленном Авижении (к поверхности ими в глубину) у водоросли Nereocystis luetkeana. Проведены наблюдения за растениями Nereocystis luetkeana (бурые водоросли) в прибрежных водах Тихого океана у города Виктории (Британская Комумбия, тихоокеанское побережье Северной Америки). Обнаружено, что в условиях максимального солнечного освещения (с восхода Ао ранних часов пополудни) водоросли систематически всплывают на поверхность, а с закатом их зеленые части погружаются в глубину (в течение примерно получаса), оставцяя на поверхности газовые пузыри. Эти ежесуточные направленные перемещения (в отличие от случайных, ненаправленных, вызванных приливами, ветрами и т.А.) не были описаны у водорослей, которые считались слишком примитивными ААя Авижений, координированных на уровне целого организма. Суточные ритмы у водорослей были известны Аишь на внутриклеточном уровне: в молекулярной регуляции митозов, фотосинтеза и иногда роста спорофитов.

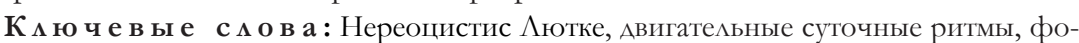
тотропизм, направАенная подвижность

\section{INTRODUCTION}

Nereocystis luetkeana (K. Mertens) Postels et Ruprecht (bull kelp) (Laminariaceae, Laminariales, Phaeophyceae), believed to have appeared in the Miocene, some 20 million years ago, and is widely distributed along the Pacific Coast of North America (Springer et al. 2007).

The largest kelp (Macrocystis) exhibit one stipe (that can be 30 to $80 \mathrm{~m}$ long), attached to the bottom, with its distal end showing the ability to float due to a small gasfilled bulb with the leaf-like blades radiating from the bulb and enhancing photosynthesis. Laminariales are the largest photosynthetic organisms in aquatic world.

Circadian rhythms at the level of the entire organism, as documented in this paper, have not yet been recorded in the literature to our knowledge. There is some body of literature recording circadian rhythms at the biochemical level as well as in the mitotic activity (that is growth) in algae but all those were observed at the intracellular (molecular) level and as such bear only indirect relevance to our topic. Below are a few examples.

Some algae are known to display intracellular chemical circadian rhythms (that is at the molecular level) of naturally light-dependent photosynthetic activity: it is most active in the morning, declines by noon (sometimes as much as by $50-60 \%$ ), recovers in the afternoon and comes to halt at dusk. The noon decline reflects temporary photo-inhibition by highest solar illumination, exacerbated by high UV.

"During photo-inhibition the energy that has been absorbed but not used in photochemical reactions, is dissipated in the form of thermal radiation or fluorescence" (Graham \& Wilcox 2000: 617). And “...bio-luminiscence (as shown in Dinoflagellates) is known to involve endogenous 
circadian rhythms" (Graham \& Wilcox 2000: 211). So, it was known that some algae have built-in biological clock, that controls their circadian rhythms at the molecular level.

Furthermore, circadian rhythms may control growth of juvenile sporophytes (Lüning 1994, Zhang \& Pang 2007) and even the blades (Lüning 1991) in some species. The vertebrate pineal gland hormone melatonin is produced by the multicellular brown alga Pterygophora californica and mimics dark effects on growth rate in the light (Fuhrberg et al. 1996).

As an underlying principle in such species the mitotic cycle appears to be strongly coupled to the circadian clock allowing mitosis only during certain phases of the circadian cycle.

Early botanists knew that searching for nuclear division stages was successful in multicellular algae in certain species only at night time (Lüning 1994). In other words, mitotic activity (growth, proliferation, reproduction) of some algae was also shown to be under control of the biological clock.

What about the directional or vector motility? The process is principally different from growth in many aspects, is not usually based on mitotic activity and to our knowledge has not yet been recorded.

Our goal was to observe whether part of the absorbed but not used energy might not only get dissipated but also elicit the directional diurnal motility (coordinated at the level of the entire organism) that is surface-floating versus immersion of its stipes and blade 'forests'. Is it actively controlled through the diurnal vector-positional changes or does it occur only passively haphazardly depending solely on tides, storms and random water turbulence?

\section{MATERIAL AND METHODS}

We studied Nereocystis luetkeana at the Ogden Point of the harbor, Victoria, British Columbia, in an area about $500 \mathrm{~m}$ long of the seaward middle third of the breakwater (between its two bents), where kelp forms loosely defined aggregations (labelled as the "colonies" 'B', 'P', 'A', 'CB' and 'DS' though they are not real colonies) as well as spreads in smaller groups between them.

113 photographs were analyzed of the kelp sunlight versus at dusk, taken in September 2014. Pictures were taken by the digital NIKON D70 camera vintage 2004, always at the same magnification [the focal length is $30 \mathrm{~mm}$ (moderate wide-angle), then cropped approximately to $75 \%$ of the full frame for the final image] at the same time every day: between 12:25 and 14:30 $\mathrm{hr}$ and again at sunset (19:40 to 19:55 hr), as well as 39-45 minutes after sunrise (07:18 hr).

Weather: clear, day temperature $18^{\circ}$ to $23^{\circ} \mathrm{C}$, night $15-$ $17^{\circ} \mathrm{C}$. Water $14-16^{\circ} \mathrm{C}$. Ocean calm; wind below 3-6 km/ hour (except on September 8, when it was $23 \mathrm{~km} / \mathrm{hr}$ as seen in the photo E, Fig. 3).

The tide charts showed that the tides in the harbor at the time were about $2.2 \mathrm{~m}$ high around 14:00 hr while down to $1.6 \mathrm{~m}$ at sunset.

Always the same colonies were targeted at photographing as much as possible (Fig. $1 \mathrm{~A}$ and B, note the same buoy (upper right and upper left corner of images respectively), the only buoy at the breakwater).

We assessed the results (the floating exposure of the stipes and visibility of the blade forests) on a scale from grade ' 1 ' (minimal) to ' 6 ' (maximal).

The assessment was done blindly that is without having known at the time of the assessment, when the picture had been taken. This is a subjective way to semi-quantitatively assess the data, otherwise resisting quantization.

On our scale ' 1 ' is used when: the bulbs float on the surface with very occasional short immediately adjacent segments of stipes exposed; most of the stipes and blades are immersed deep enough to be non-observable from the breakwater (Figs. 1B, 2I and 3D).

On our scale ' 6 ' means abundant stipes in great length are seen afloat and the numerous blade forests are easily observable (Figs. 1A, 2 A to F and 3A). Grades '2' to '5' are in-between steps of gradually advancing floating exposure.

\section{R E S U LTS}

It yielded the following (Fig. 4):

1) the colony 'B' (at the buoy), when sunlight, showed in 10 photographs the daily variations from ' 4.2 ' to ' 5.5 ' with the average ' 4.9 '; at dusk in 9 photographs between '1.3' and '2.7' with the average '1.9' that is at dusk floating as compared with sunlight was half as active.
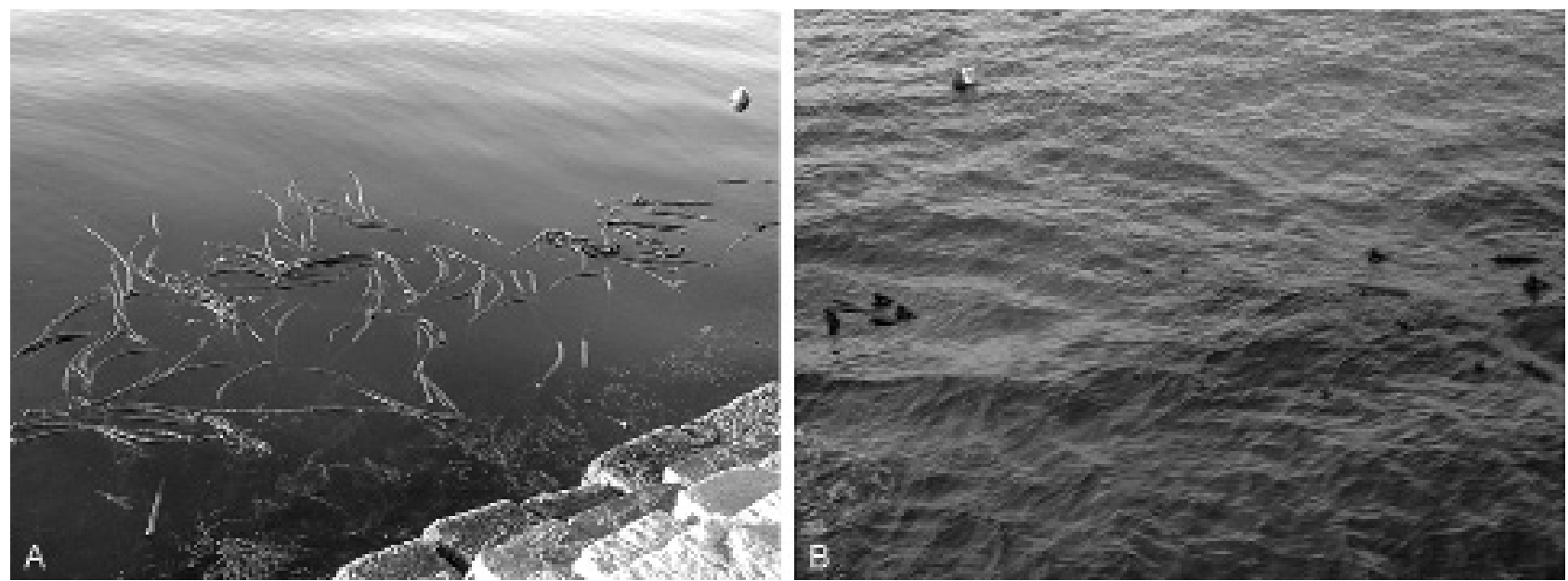

Figure 1 Same colonies photographed at different time of different days. Colony 'B' at the buoy taken at 14:25 in full sun (image A) shows extensive floating (grade 6); same colony pictured at 19:45 (5 minutes past sunset): stipes and blades immersed (grade 1) 

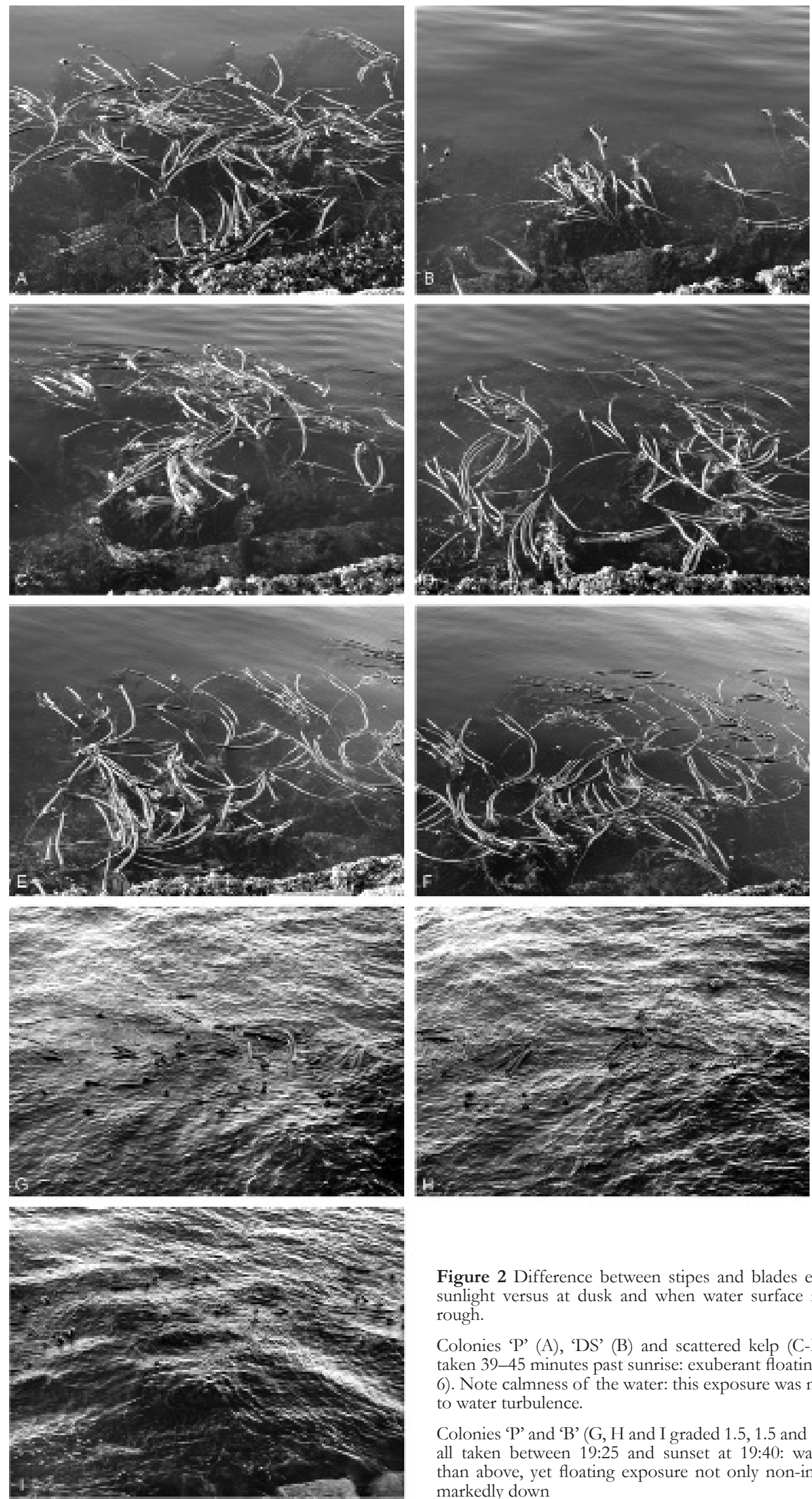

Figure 2 Difference between stipes and blades exposure when sunlight versus at dusk and when water surface is calm versus rough.

Colonies 'P' (A), 'DS' (B) and scattered kelp (C-F). All photos taken 39-45 minutes past sunrise: exuberant floating (each graded 6). Note calmness of the water: this exposure was not passive due to water turbulence.

Colonies 'P' and 'B' (G, H and I graded 1.5, 1.5 and 1 respectively), all taken between 19:25 and sunset at 19:40: water is rougher than above, yet floating exposure not only non-increased but is markedly down 

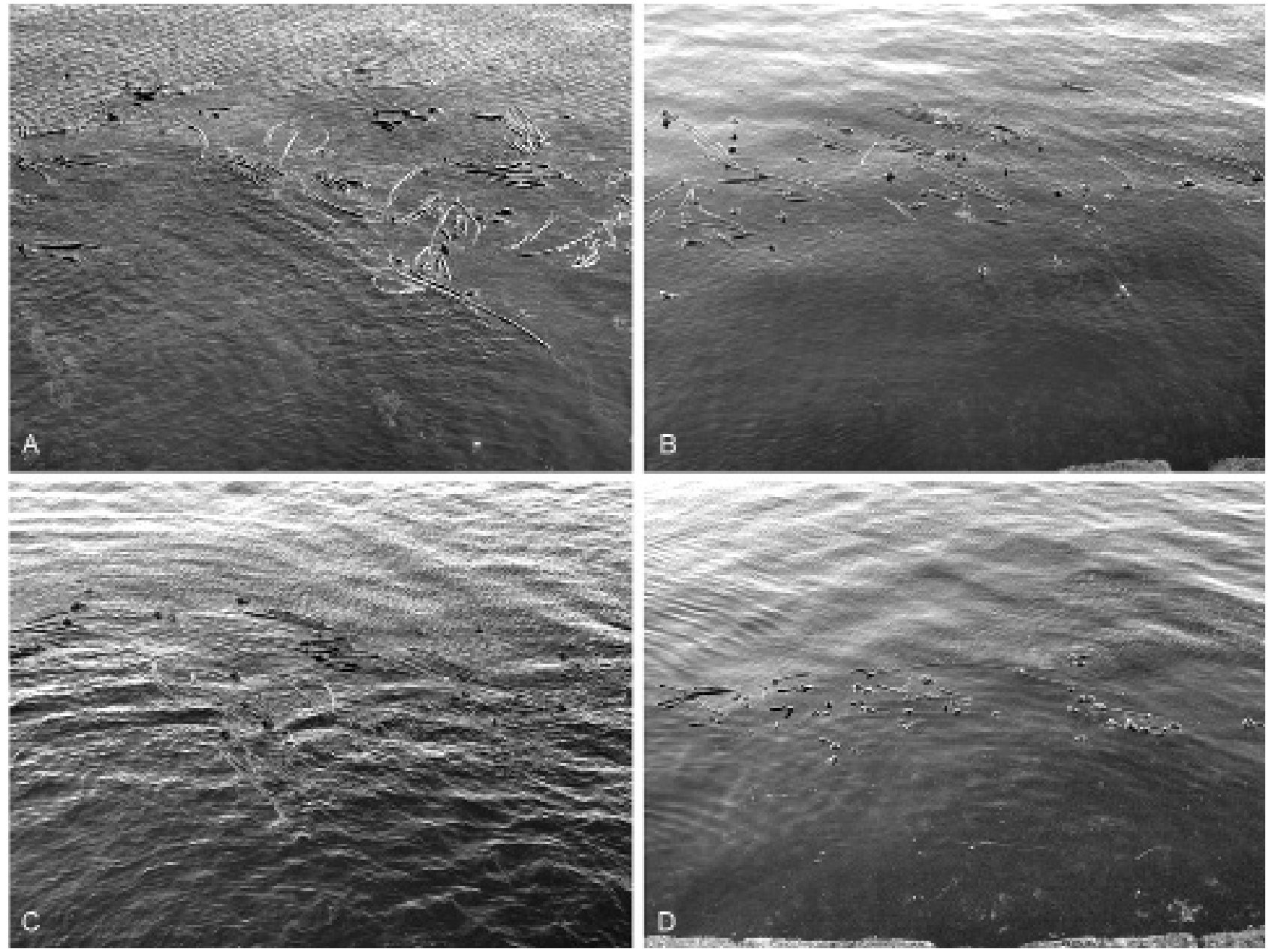

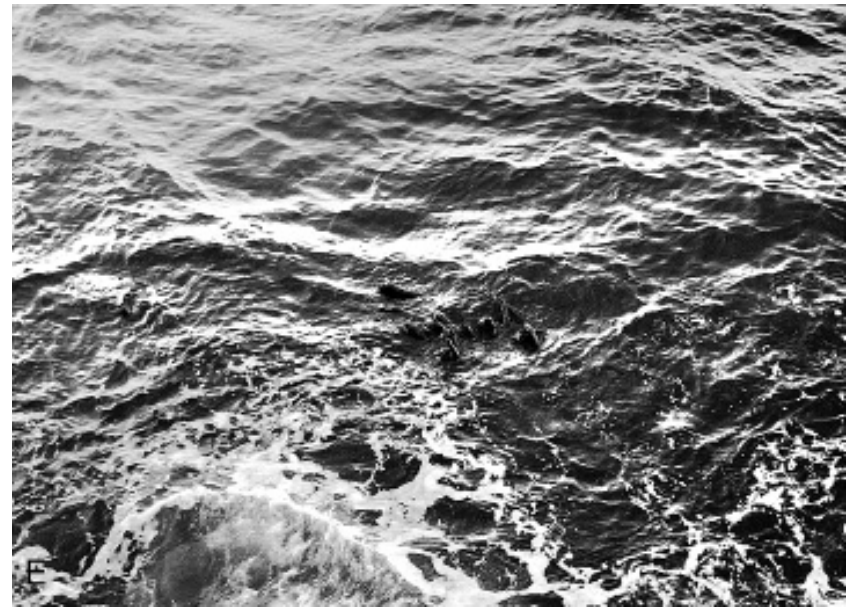

2) 'P', when sunlight, in 12 photographs showed daily variations from ' 4 ' to ' 6 ' with the average ' 5.2 '; at dusk in 10 photographs from '1.6' to '2.5' with the average '2.3' (Fig. 2) that is almost half of its daytime activity.

3) 'A', when sunlight, in 13 photographs from ' 4.5 ' to ' 6 ', with the average ' 5.1 '; at dusk in 8 photographs from ' 1.5 ' to ' 2.5 ' with the average ' 1.9 ' that is less than half as active as at daytime.

4) ' $\mathrm{CB}$ ', when sunlight, in 10 photographs from ' 4,3 ' to ' 6 ' with the average ' 5,0 '; at dusk in 10 photographs from '1.2' to ' 2.3 ' with the average ' 1.7 ' (Fig. 3) that is less than half as active.
Figure 3 Diurnal dynamics of floating, colony 'CB'. Photo A taken at 13:35 (grade 6); photos B and C taken 20 minutes before sunset each (grades 2 amd 1.5 respectively), and photo D taken within 5 minutes before sunset (grade 1).

Water turbulence does not determine extensive floating exposure as seen in photo $A$, while the water serface is calm versus photo $E$ taken at sunset: rough with waves and foam water, yet, the stipes' exposure is minimal (grade 1)

5) 'DS', when sunlight, in 12 photographs from ' 3 ' to '5.9' with the average ' 5.1 '; at dusk in 10 photographs from ' 1.4 ' to ' 1.5 ' with the average ' 1.5 ' that is is less than a half of its daytime activity.

6) And the various loose kelp between the kelp aggregations, when sunlight, in 12 photographs from ' 4.5 ' to ' 6 ' with the average ' 5.5 ' and at dusk in 17 photographs from ' 1.5 ' to ' 2.5 ' with the average ' 2.3 ' that is over a half down.

Summing up:

1. Total average: floating of the kelp when sunlight was '5.1' (59 photographs) versus at dusk '1.9' (54 photographs). 


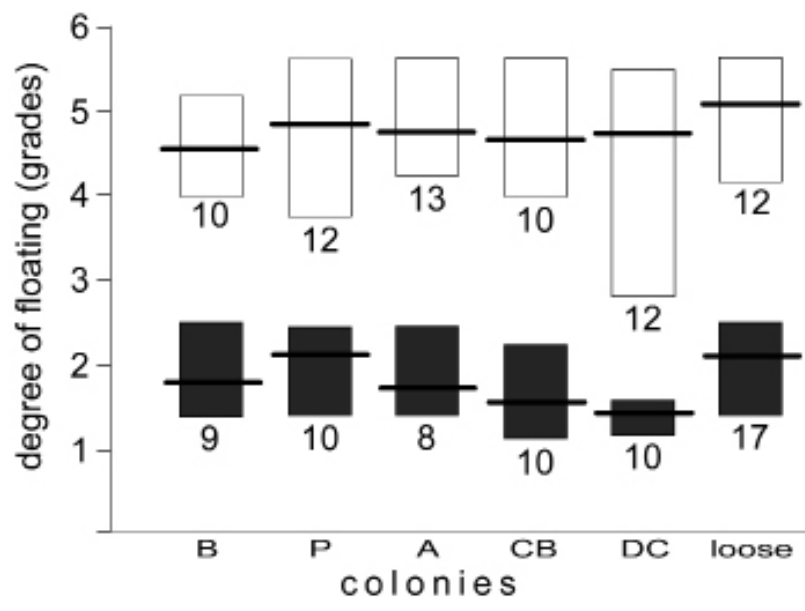

Figure 4 Floating of stipes and blades of Nereocystis luetkeana when sunlight versus at dusk. Clear bars refer to floating when sunlight and shaded to at dusk (minimum - maximum grades); bold line crosses bar at average grade; the numbers next to bars are numbers of observations

The results show that diurnal fading of sunlight at dusk within 1-2 hours consistently reduces the surface floating and enhances deeper immersion of the stipes and blades (from ' 5 ' to ' 2 ').

2. At sunrise the light, conversely, enhances the surface floating to a maximal degree (' 6 ') less than in 40 minutes.

It is safe to assume that if the pictures taken at dusk could have been taken in the real post-sunset darkness, the immersion of the stipes/blades would be further enhanced: an example of this situation is the colony ' $\mathrm{B}$ '. When photographed in twilight ( 25 to 15 minutes before sunset) it showed grade ' 1.5 ', while photographed 5 minutes after sunset already down to '1' (Figs. $2 \mathrm{H}$ versus $3 \mathrm{E}$ and Fig. $3 \mathrm{~B}$ and $\mathrm{C}$ versus $\mathrm{D})$.

Of note is how fast the changes occur not only at dusk but also at the morning dawn. The pictures taken 39-45 minutes after sunrise showed the surface floating exuberantly exposed (Fig. 2 A to F).

\section{DISCUSSION}

Let's start with the known intracellular circadian rhythms. It is only natural to observe diurnal rhythms in sun-dependent intracellular chemical activity (such as in photosynthesis). Another (and connected) case of intracellular chemical circadian rhythms is the activity of nitrogenase, the enzyme, critical in binding inorganic nitrogen for protein synthesis: the nitrogenase needs energy of the ATP created during photosynthesis (reported in the Trichodesmium).

Circadian rhythms in some multicellular algae, as quoted above, are found in control of mitotic activity, hence of growth of sporophyte and reproduction of some algae (Lüning 1991, 1994, Zhang \& Pang 2007).

However, to our knowledge there were no records of diurnal rhythms in the directional motional light-dependent activity (phototropism) coordinated at the level of the whole organism in kelp. The assumed hypothesis has been that the kelp can only be moved randomly and passively with the currents generated by tidal activity, wind, boats, etc.
Current findings may contribute in dispelling this not uncommon misconception. Water turbulence should be, indeed, instrumental in kelp movements; however, had it been the only force, it should be sensible to expect that the low tides and high turbulence would "uncover", hence facilitate the stipes/blades surface-floating exposure.

Counter-intuitively, between 12:30 and 14:30 hr, when tides are high (about $2.2 \mathrm{~m}$ ), the floating exposure, too, is high as opposed to the sunset time (19:40 hr), when exposure and the tides $(1.6 \mathrm{~m})$ are both low (Figs. 1-3).

Similarly, the rough water facilitates the stipes/blades' surface exposure much less (if at all - see Fig. 3E, photo taken at sunset while the ocean was rough) than sunshine even when the ocean is calm (Fig. 3A, photo taken at 13:40 hr).

So, clearly, some forces other than tides and turbulence, some inherent innate forces actively govern the kelp vector motional responses to the diurnal smiles and frowns of our celestial life-giver.

This heterochronism in developing adaptations (that is a deviation from the typical time-related sequence in the formation of organs or functions like in this case of a surprisingly early motional phototropism in the protist) is all about survival of the fittest, about the role of selection in evolution. Such heterochronism is not well explored for the most part: how far back in evolution do the 'disproportionally sophisticated' selection-driven adaptations go? May there be some other than via "nerves and muscles" hypothetical pathways of that early phototropism, is it possible to try to figure it out?

Motional diurnal rhythms as a phototropic response, are recorded in the directional curvature of the plant parts in their reaction to light (like in sunflower). Positive phototropism or curving toward the light is the feature of stems and leaves while roots exhibit negative phototropism and gravitropism. It is known that many mechanical leaf responses occur due to reversible swelling/shrinking of specialized cells, whereas all stem and root phototropic responses are due to a different pathway: the cell elongation as a result of differential responsiveness to the plant hormone auxin (but none involves mitotic activity). Auxin causes the plant to have elongated cells on the farthest side from the light by activating proton pumps, hence decreasing the $\mathrm{pH}$ in the cells on the dark side of the plant. This activates the enzymes known as expansins, which break bonds in the cell membrane, making the cell walls less rigid. The decrease in wall strength causes cells to change shape, exerting the mechanical pressure that results in phototropic vector (light-directioned) movements (Pedmale Ullas et al. 2010). More research is needed but this might be one hypothetical pathway for the observed heterochronism.

\section{CONCLUSIONS}

1. Nereocystis luetkeana exhibits active directional lightdependent motions of its stipes/blades: they surface when sunlight and get immersed deeper during twilight, their floating less than a half of its daytime activity by sunset (with the bulbs remaining on the surface, hence observable).

2. Those vector motions are active (as opposed to passive random migration and relocation following the tides and water turbulence) and exhibit previously unrecorded in 
kelp circadian rhythms coordinated at the level of the entire organism.

3. Light-dependent motions in the stipes/blades' position (floating versus immersion) occur fast with the change of light, perhaps, as fast as within half-an-hour.

4. It seems that biological clock exerts continuous circadian control of kelp active directional (floating versus immersion) motions rather than being only a switch on/ off for the light/darkness cycles. The stipes spread floating on the surface exuberantly (' 6 ') in the morning and early afternoon only to start gradually sinking down later in the afternoon with the fading of sky light, though it is still long hours before the dusk really darkens the sky. Correspondingly, assessed in the morning/noon as reaching ' 6 ' same aggregations by 16:00-17:00 hr (good two hours before sunset) may only merit in our grading system ' 4 ' or even ' 3 '. It drops after evening twilight descends on the area (Fig. 1-3).

Further observations are needed, on other kelp and in other coasts, as well as in the regular short-time intervals. When confirmed, this will contribute to our understanding of selection-directed adaptations and their time and role in evolution.

\section{ACKNOWLEG MENTS}

Both authors wish to acknowledge with gratitude the help of Mrs. Denise Sketches in computer processing of this article.

\section{LITERATURE CITED}

Fuhrberg, B., I. Balzer, R. Hardeland, A. Werner \& K. Lüning 1996. The vertebrate pineal hormone melatonin is produced by the brown alga Pterygophora californica and mimics dark effects on growth rate in the light. Planta 200(2):125-131.

Graham, L.E. \& L.W. Wilcox 2000. Algae. Prentice Hall, Upper Saddle River, New Jersey, 660 pp.

Lüning, K. 1991. Circannual Growth Rhythm in a Brown Alga, Pterygophora californica. Botanica Acta 104(3):157162.

Lüning, K. 1994. Circadian growth rhythm in juvenive sporophytes of Laminariales (Phaeophyta). Journal of Phycology 30 (2):193-199.

Pedmale U.V., R.B. Celaya \& E. Liscum 2010. Phototropism: Mechanisms and Outcomes. Arabidopsis Book 8: e0125 (August 31, 2010 online).

Springer, Y., C. Hays, M. Carr, M. Mackey 2007. Ecology and management of the bull kelp. Nereocystis luetkeana: A Synthesis with Recommendations for Future Research. Lenfest Ocean Program, Washingtot, DC, 48 pp.

Zhang, Zh. \& Sh. Pang 2007. Circadian growth rhythm of the juvenile sporophyte in brown algae. Acta Oceanologica Sinica 26(2):104-111. 